\title{
Peranan Sertifikasi Kompetensi Loading Master dalam Perhitungan Volume Lifting Minyak Bumi
}

\author{
Mohammad Hasan Syukur
}

Pusat Pengembangan Sumber Daya Manusia Minyak dan Gas Bumi, Cepu

\begin{abstract}
ABSTRAK
Realisasi lifting minyak bumi sampai dengan Desember 2018 mencapai 778 MBOPD atau sebesar 97.3\% dari target 800 MBOPD yang ditetapkan dalam Tahun 2018 (Lakin Ditjen Migas, 2019). lifting adalah Produksi migas yang telah siap jual. Istilah lifting juga kerap digunakan untuk menggambarkan proses distribusi migas dari produsen ke pembeli. Ketika lifting migas terpenuhi, penerimaan negara dari kegiatan hulu migas pun terealisasi. lifting migas merupakan proses penting dalam industri hulu migas. Oleh karena itu peranan Loading Master dalam Pengukuran dan penghitungan penerimaan minyak dari fasilitas produksi lapangan, Penampungan minyak dari fasilitas produksi lapangan untuk penjualan, Penghitungan stok minyak, Pelaksanaan lifting, Dokumentasi lifting. Adalah hal hal yang harus diperhatikan dan itu semua dalah tugas dari seorang Loading Master . Sampai tulisan ini dibuat Loading Master data LSP PPT MIGAS 156 orang yang mengambil sertifikasi kompetensi Loading Master .
\end{abstract}

Kata kunci: lifting, Loading Master, Sertifikasi Kompetensi

\section{PENDAHULUAN}

Pada pemahaman bisnis internasional, minyak mentah dan gas alam yang diangkat ke permukaan disebut "lifting". Namun di Indonesia, pemahaman tersebut bebeda. Minyak mentah dan gas bumi yang di angkat dari dalam perut bumi disebut dengan data produksi. Sedangkan data lifting dipahami sebagai gas bumi dan minyak mentah yang dapat di angkat ke permukaan dan dijual.

Mengenai data produksi, titik ukurnya dinilai dari jumlah migas yang dapat dikeluarkan dari dalam reservoir melalui sumur-sumur produksi yang ada. Sedangkan titik ukur data lifting dinilai dari titik penjualan atau sering juga disebut "titik serah" atau dalam bahasa Inggris disebut custody transfer point atau point of delivery.

Karena kedua istilah tersebut dinilai/diukur dari titik yang berbeda, maka angka lifting seringkali berbeda dengan angka produksi. Mengapa? Karena dalam kondisi tertentu, hasil produksi yang telah dikumpulkan pada tangki penyimpanan tidak dapat diangkut dan dijual seluruhnya. Hal tersebut umumnya disebabkan oleh ketersediaan dan terbatasnya kapasitas angkutan kapal untuk mengangkut minyak maupun gas hasil produksi.

Perbedaan tersebut bisa juga terjadi akibat kapasitas sumur produksi yang sangat kecil, sehingga untuk melakukan penjualan minyak dan gas dibutuhkan waktu pengumpulan yang lebih lama. Misalnya saja satu sumur minyak mampu memproduksi setiap bulan 100.000 barrel 
sementara kebutuhan lifting yakni 300.000 barrel. Anggap saja bulan ini bulan Januari, tetapi karena alasan efesiensi, maka lifting baru akan dilakukan 3 bulan sekali karena menunggu sampai terkumpulnya minyak mentah sebesar 300.000 barrel tadi. Dengan jumlah produksi tersebut, maka lifting akan dilakukan pada akhir bulan Maret atau awal bulan April. Jadi, kalau ditanya berapa data produksi pada bulan April, maka jawabannya jelas 100.000 barrel.

Angka - angka dalam perhitungan adalah yang diperoleh dari data pengukuran baik secara automatic maupun secara manual gauging. Sedangkan Sumber Daya Manusia (SDM) yang melakukan verifikasi dan tanda tangan dalam dokumen serah terima dan pengukuran tersebut adalah Loading Master di lokasi custody transfer. Oleh karena itu peranan Loading Master dalam ketepatan dan kompetensinya adalah sangat dibutuhkan dalam peningkatan lifting migas.

\section{TINJAUAN PUSTAKA}

\section{A. Perbedaan Produksi dan lifting}

Pasca penemuan cadangan migas baru dan terbangunnya seluruh fasilitas produksi, kegiatan usaha hulu migas berlanjut ke tahap produksi. Dalam fase ini, migas yang tersimpan di dalam perut bumi mulai diangkat ke permukaan. Besaran minyak maupun gas bumi yang bisa diangkat ke permukaan melalui sumur-sumur produksi dikenal dengan istilah data produksi.

Migas yang berhasil diangkat kepermukaan selanjutnya diolah di fasilitas pemrosesan. Kegiatan ini dilakukan untuk memisahkan minyak maupun gas bumi dari material dan mineral lain yang tidak dibutuhkan. Dari fasilitas pemrosesan, migas selanjutnya dikumpulkan dalam tempat penampungan (storage) hingga jumlahnya mencukupi untuk diserahkan ke pihak pembeli.

Produksi migas yang siap jual tersebut dikenal dengan istilah lifting. Besaran lifting inilah yang menjadi dasar penghitungan bagi hasil antara pemerintah Indonesia dengan kontraktor yang menjadi pengelola suatu wilayah kerja migas.

Hal inilah yang sering menjadi perdebatan karena laporan produksi yang diberikan oleh kontraktor adalah data produksi yang keluar dari mulut sumur sebelum dilakukan pemrosesan, pemisahan, pembersihan dari impurities, sehingga data produksi bukanlah data yang dijadikan acuan untuk perhitungan bagi hasil antara negara (pemerintah pusat), kontraktor dan pemerintah daerah yang mendapatkan dana bagi hasil migas.

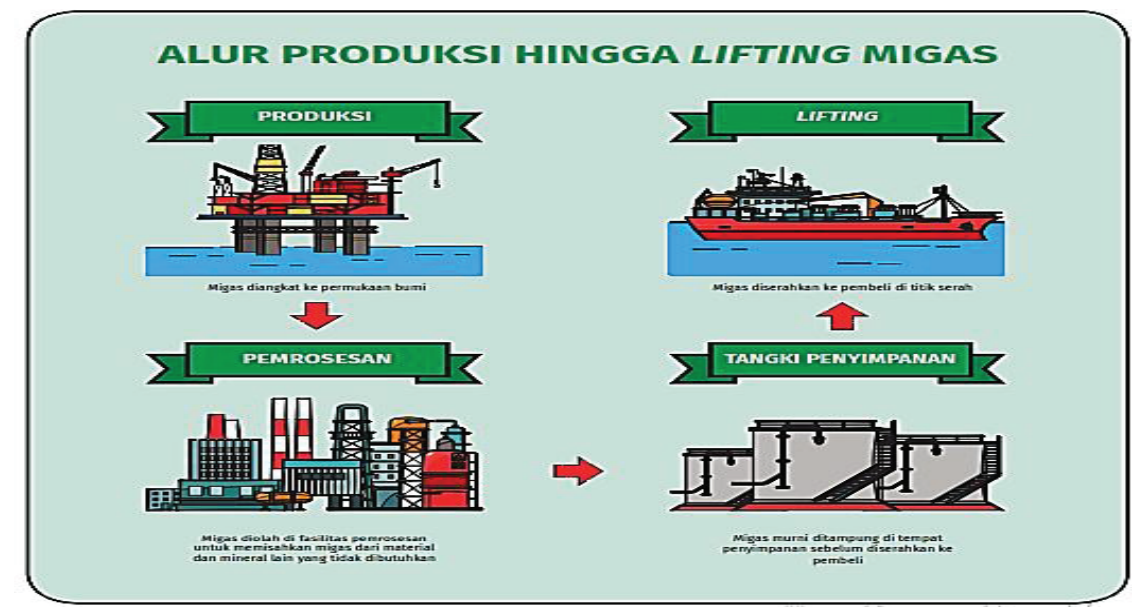

Gambar 1. Alur Produksi Migas dan perbedaan Produksi dan lifting 
Lifting migas merupakan proses penting dalam industri hulu migas. Karena di sinilah pendapatan negara dari sektor industri hulu migas didapat. Pada tahap awal, pengawasan dilakukan SKK Migas dalam penentuan dan perumusan kontrak perjanjian jual-beli minyak maupun gas bumi dengan pembeli. harga jual minyak atau gas bumi termasuk elemen yang dipertimbangkan dalam perumusan ini. SKK Migas berkepentingan mendapatkan harga yang menguntungkan bagi negara. Harga gas dalam setiap kesepakatan jual-beli ditetapkan oleh Menteri Energi dan Sumber Daya Mineral (ESDM). Sedangkan, harga minyak mengacu pada harga minyak mentah indonesia (Indonesian Crude Price/ICP) yang ditetapkan oleh Kementerian ESDM tiap bulan. Kontrak perjanjian jual-beli migas harus sudah disepakati sebelum lifting dilakukan, bahkan sebelum lapangan mulai berproduksi. KKKS berkewajiban mencari pembeli dan penandatangani kontrak jual-beli sebelum proses produksi migas dimulai. Kontrak tersebut menjadi jaminan bahwa migas yang telah diproduksikan nantinya benar-benar tersalurkan ke pembeli dan tidak bertimbun di tempat penampungan.

Setelah kontrak jual-beli ditandatangani dan lapangan migas mulai berproduksi, negara selanjutnya melakukan pengawasan pada teknis lifting. SKK Migas mengawasi lifting di titik-titik penyerahan migas. titik penyerahan adalah lokasi tempat kontraktor KKS wajib menyerahkan migas yang menjadi bagian negara kepada pemerintah. Di titik penyerahan, KKKS juga sudah bisa mengklaim migas hasil produksi, yang menjadi bagiannya sesuai kesepakatan dalam kontrak kerja sama (MIGAS, 2019)

Berdasarkan data perolehan lifting minyak bumi 2018, Mobil Cepu Ltd dan PT. Chevron Pacific Indonesia merupakan dua Kontraktor Kontrak Kerjasama (KKKS) migas yang memberikan kontribusi terbanyak volume lifting minyak bumi nasional. PT. Chevron Pacific Indonesia memberikan kontribusi perolehan lifting minyak bumi Indonesia sebesar $26.92 \%$ dari volume total dan Mobil Cepu Ltd. memberikan kontribusi perolehan lifting minyak bumi Indonesia sebesar 26.90\%. (MIGAS D. J., 2019)

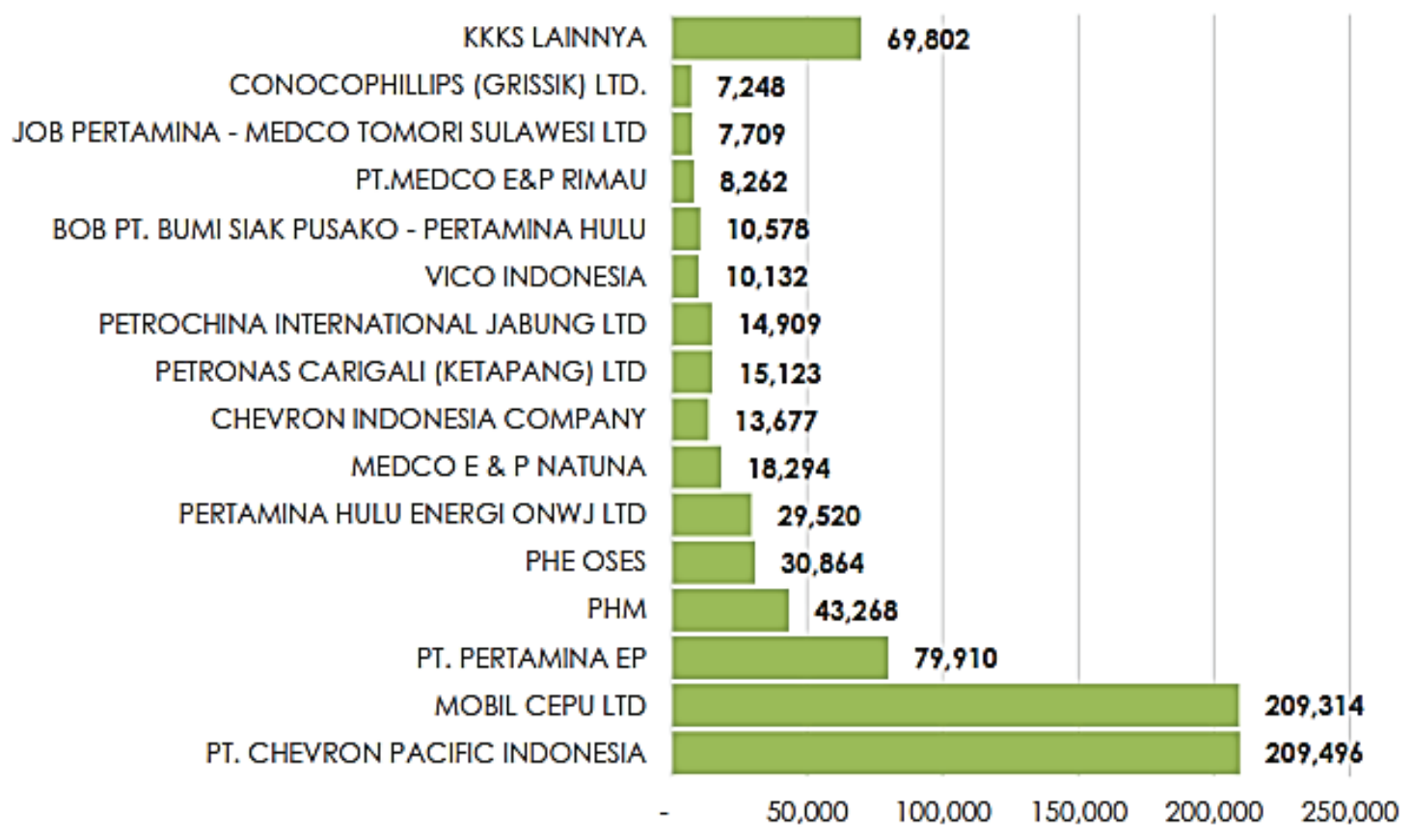

Gambar 2. lifting Migas 2018 (MIGAS D. J., 2019) 


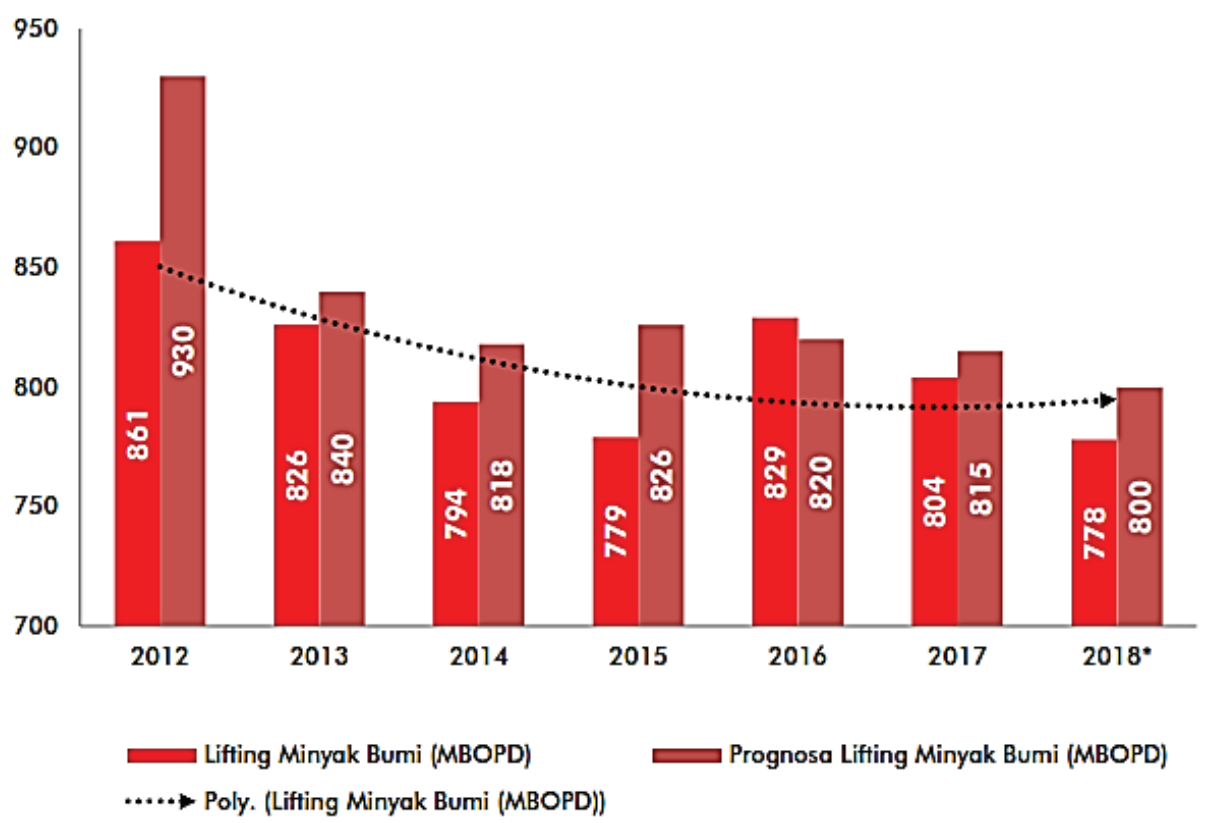

Gambar 3. Prognosa dan Realisasi lifting Minyak Bumi Tahun 2012 - 2018 (MIGAS D. J., 2019)

Proses produksi merupakan kegiatan utama dalam industri hulu migas. Kegiatan usaha hulu migas terdiri atas eksplorasi dan eksploitasi. Kegiatan eksplorasi bertujuan untuk menemukan cadangan migas. Kegiatan eksploitasi terbagi dalam dua tahap yaitu tahap pengembangan dan tahap produksi. Pada tahap pengembangan, KKKS menyiapkan segala fasilitas yang dibutuhkan untuk masuk dalam tahap produksi. Sedangkan pada tahap produksi, KKKS menggali dan mengangkat minyak dan gas bumi dari dalam perut bumi, lalu diproses untuk menghasilkan minyak dan gas bumi yang siap dijual.

Tidak semua migas yang diproduksi tersebut dapat langsung dijual. Produksi migas tersebut masih harus diproses dan diangkut hingga siap dijual. Produksi migas yang telah siap jual inilah yang disebut dengan istilah lifting. Istilah lifting juga kerap digunakan untuk menggambarkan proses distribusi migas dari produsen ke pembeli. Ketika lifting migas terpenuhi, penerimaan negara dari kegiatan hulu migas pun terealisasi. (MIGAS, 2019)

Disinilah peranan Loading Master untuk mengamankan asset negara dalam kegiatan lifting dengan pengukuran dan perhitungan yang tepat. Loading Master, insan terbaik pengelola terminal dan dermaga, mengelola proses serah terima Migas di seluruh wilayah Nusantara, migas adalah komoditas strategis yang nilainya luar biasa. Tak ingin sedikitpun ada bagian yang tercecer hilang tak jelas rimbanya, karena paham migas itu adalah sesungguhnya milik negara. 


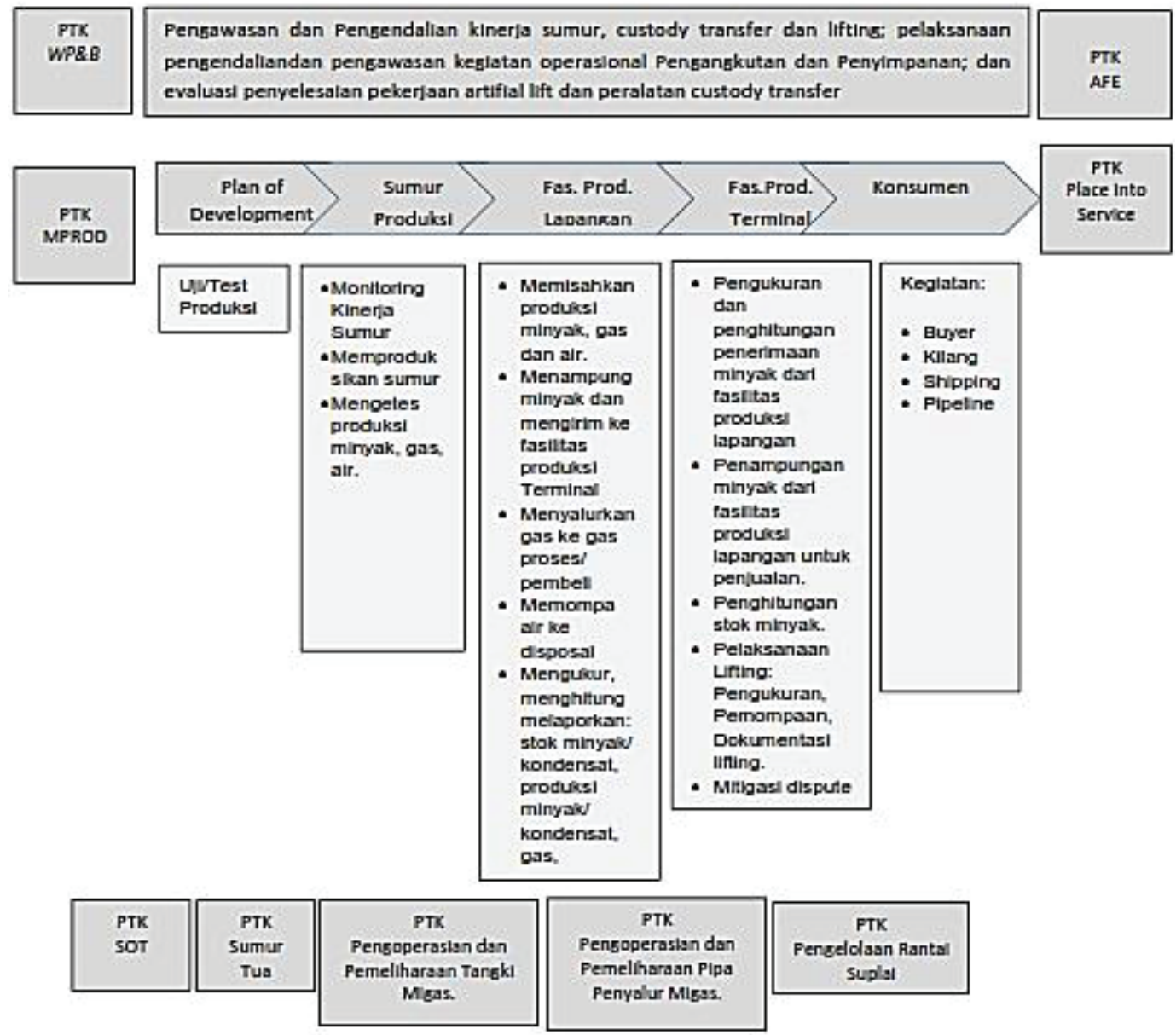

Gambar 4. Pedoman Tata Kerja Manajemen Produksi Minyak dan Gas Bumi (MIGAS S. , 2016)

Dari Gambar 4 dijelaskan bahwa dalam kegiatan kegiatan Loading Master terintegrasi mulai kegiatan lapangan dan kegiatan di terminal, sampai menganalisa dispute.

\section{B. Tugas Loading Master}

Sesuai dengan judul akan di jelaskan tugas seorang Loading Master ketika sedang bertugas di atas kapal tanker, mulai dari kapal tanker yang berukuran panjang LOA 100-180 meter dan Kapal Super Tanker (250-350 meter)

Segala hal disiapkan oleh seorang Loading Master dalam mengngendalikan pemuatan cargo via darat ke kapal. Sebelum dilakukan pemuatan cargo, ada beberapa hal yg akan dicek disaat sedang komunikasi bersama chief officer, Surveyor dan Loading Master, pengecekan Ship/Shore Safety Checklist (berperan dalam kelancaran pemuatan), Perencanaan Sequencess of Loading 
(grade, parcel dan rencana muat), Pengecekan Kebersihan Tangki Kapal (Tanks Inspection) dan jika Tangki Kapal Bersih akan dikeluarkan Dry/ Empty Certificate dari Surveyor, Pengecekan Vessel Experience Factor, NOR / Notice Of Readiness, Last Three Cargo (ini termasuk penting) sebab last three cargo adalah sebuah kertas yang bertuliskan tentang apakah sebelum nya kapal pernah memuat minyak atau cargo apa saja, misal nya seperti Chemical Oil (Kimia), Crude Palm Oil ( Minyak Kelapa Sawit dan Turunan nya), atau pun pernah memuat Crude Oil and Products (Minyak Bumi dan Produk produknya). Setelah selesai Komunikasi maka akan dilakukan pemuatan via darat ke kapal dengan segala aktifitas loading, stop, komunikasi dengan crew kapal serta surveyor tetap dilaksanakan oleh seorang Loading Master agar terciptanya pemuatan cargo yang aman dan safety. Mencatat segala kronologis (Timesheet) dan harus di conform kan antara Time sheet Loading Master dan Officer kapal. Setelah selesai pemuatan, akan dilakukan Ullage Temperature Interface (UTI/MMC), pengukuran dengan pita ukur (Sounding Tape) atau Perhitungan di kapal disertai dengan B/L (Billing Of Loading) dari hasil pemuatan via darat. Apakah sampai sini sudah selesai? Tentu belum. Selesai perhitungan / calculation, akan di buat ullage report oleh chief officer kapal dan surveyor. Setelah selesai ya akan dilakukan komunikasi antara Loading Master dengan pihak shipper/company dan pihak kapal dengan si owner atau ke carter, jika conform, agent akan berperan untuk menyiapkan dokumen kapal untuk segera berlayar.

Loading Master, teknis pekerjaan yang rumit di berbagai moda; Shoretank diukur dengan cermat menggunakan tabel dan skala; alat transfer pompa, pipa dan dermaga diyakini handal dan senantiasa siaga, anatomi tanker dan sistem segel dikuasai untuk hindari fraud yang diusung para mafia. Tak ingin tertunda atau terlambat barang satu jam saja; Berisiko negeri ini akan lumpuh kalau migas sampai langka.

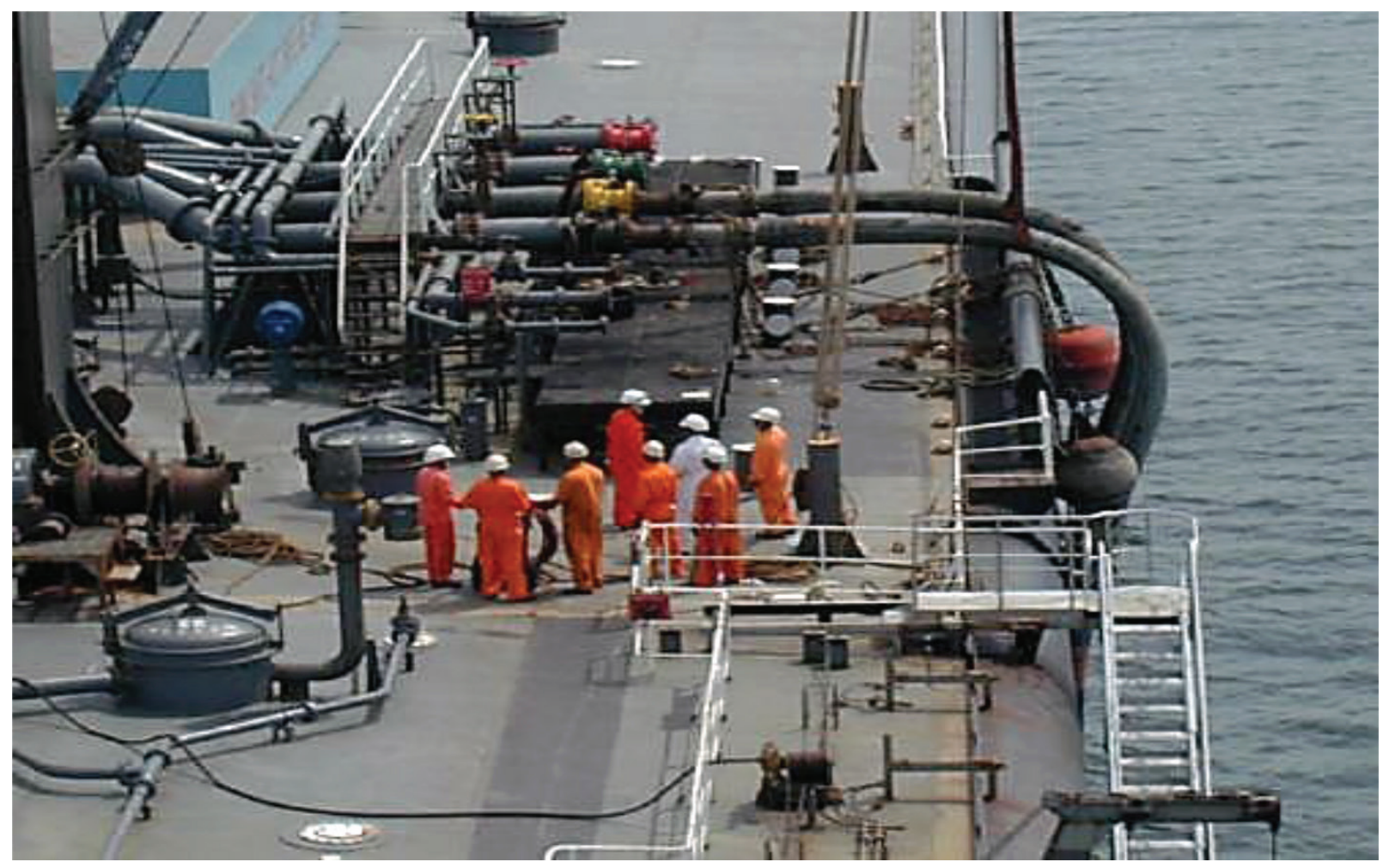

Gambar 5. Salah satu Kegiatan Loading Master di Jetty/ Pelabuhan 
Tugas Loading Master secara umum adalah :

a. Memastikan selang selang kering dan dilepaskan sebelum pergerakan kapal dan peralatan emergency shut down valve di kapal dan tangki terhubung dan berfungsi dengan baik.

b. Berkomunikasi dengan dengan nahkoda, perwira kapal dan pengawas pelabuhan untuk mengonfirmasi bahwa semua personel darat bebas dari tambatan dan gangway ada di tempat dengan aman.

c. Ikut serta dalam dalam pertemuan pra-pemuatan untuk menentukan dan mengimplementasikan urutan pemuatan seperti status tangki pada saat kedatangan, prosedur pemuatan massal, pemberat, cuaca dan kondisi laut yang diantisipasi, komunikasi dengan kapal utama \& kapal tunda serta membahas prosedur darurat.

d. Memastikan bahwa semua kegiatan pemuatan dilakukan dengan benar sesuai dengan prosedur pemuatan dan konfirmasikan ke ruang kendali bahwa kapal siap (manifold terbuka, katup tekanan / vakum valve line up, tangki kargo yang ditunjuk pada posisi terbuka) untuk menerima kargo.

e. Konfirmasikan laju pemuatan yang diatur sebelumnya dan memastikan bahwa laju pemuatan dan kuantitas dihitung dan dicatat setiap jam oleh kapal ruang utama kendali kargo dan tangki.

f. Menyimpan catatan formal dari setiap kegiatan pemuatan (Bill of lading, manifest, sertifikat ekspor, perhitungan, tanker time sheet) dan berpartisipasi dalam rapat pasca pemuatan.

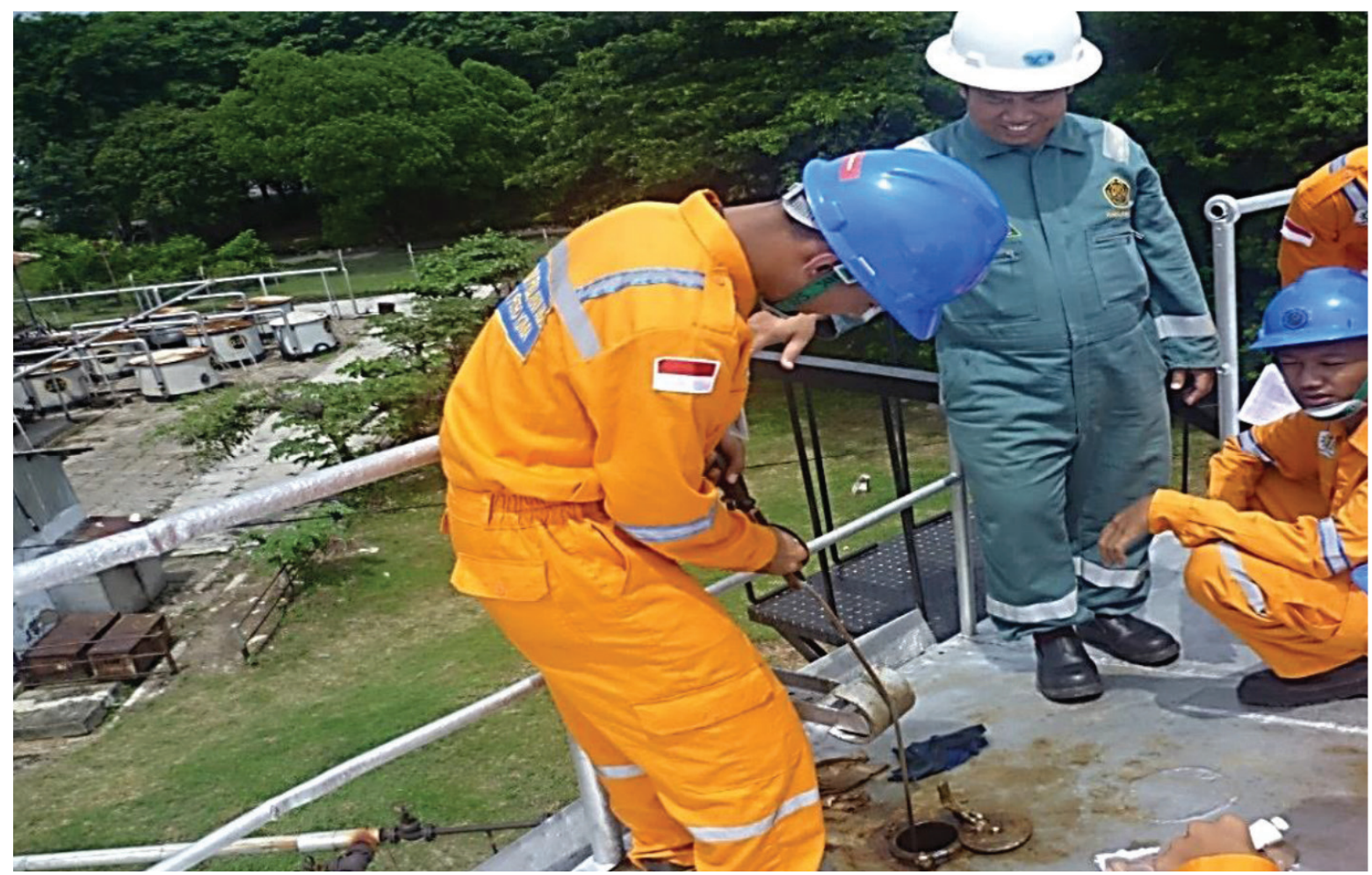

Gambar 6. Loading Master menyaksikan Petugas Pengukur Isi Tangki dalam pengukuran Level dan Isi Volume 


\section{Sertifikasi Kompetensi Loading Master .}

Peraturan Menteri Energi dan Sumber Daya Mineral (PerMen ESDM) Nomor 5 Tahun 2015 tentang Pemberlakuan Standar Kompetensi Kerja Nasional Indonesia di Bidang Kegiatan Minyak dan Gas Bumi secara Wajib menyatakan ada 35 SKKNI yang harus dilakukan di Industri Migas yang harus mempunyai SKKNI salah satu nya adalah pekerja di bidang Loading Master harus memenuhi standar kompetensi seperti pada pertauran tersebut. Sementara Standar Kompetensi Loading Master ditetapkan oleh Menteri Tenaga Kerja melalui Keputusan Menteri Tenaga Kerja Dan Transmigrasi Republik Indonesia Nomor 142 Tahun 2013 Tentang Penetapan Standar Kompetensi Kerja Nasional Indonesia Kategori Perdagangan Besar Dan Eceran; Reparasi Dan Perawatan Mobil Dan Sepeda Motor, Golongan Pokok

Perdagangan Besar, Bukan Mobil Dan Sepeda Motor, Golongan Perdagangan Besar Khusus Lainnya, Sub Golongan Perdagangan Besar Bahan Bakar Padat, Cair, Dan Gas Dan Produk Yang Berhubungan Dengan Itu (YBDI),Kelompok Perdagangan Besar Bahan Bakar Padat, Cair, Dan Gas Dan Produk Yang Berhubungan Dengan Itu (YBDI), Sub Kelompok Operasi Serah Terima Komoditi Cair Di Dermaga (Loading Master )

Dalam SKKNI tersebut menyatakan bahwa seseorang yang mengambil jabatan Loading Master sudah level 4, artinya mereka sudah bisa melakukan analisa permasalahan dalam kegiatan loading dan unloading.

Dari data SKKNI judul unit Kompetensi adalah sebagai berikut

1. G.466101.001.01 Melakukan Komunikasi di Lingkup Pekerjaan

2. G.466101.002.01 Menerapkan K3LL di Lingkup Pekerjaan

3. G.466101.003.01 Memverifikasi Kualitas Komoditi Cair

4. G.466101.004.01 Memverifikasi Hasil Pengukuran Komoditas Cair

5. G.466101.005.01 Memverifikasi Kuantitas Komoditas Cair

6. G.466101.006.01 Memeriksa Sarana dan Fasilitas Muat (Loading)/Bongkar (Unloading)

7. G. 466101.007.01 Mengatur Muat (Loading) / Bongkar (Unloading)

8. $\quad$ G.466101.008.01 Melaporkan Hasil Kegiatan Muat (Loading)/Bongkar (Unloading)

9. G.466101.009.01Merekomendasikan Keputusan Muat (Loading) / Bongkar (Unloading) Berdasarkan Dokumen Muatan

10. G.466101.010.01 Memecahkan Permasalahan Kegiatan Muat (Loading) / Bongkar (Unloading)

\section{METODE PENELITIAN}

Metode yang digunakan dengan pendekatan deskriptif kuantitatif, penelitian dilakukan di LSP PPT MIGAS, Lembaga Sertifikasi Profesi milik PPSDM MIGAS 


\section{HASIL PENELITIAN DAN PEMBAHASAN}

Provinsi Riau menjadi penyumbang terbesar produksi minyak mentah dan kondensat secara nasional. Dari target lifting 775 ribu barel per hari, per Januari 2019, dari perut bumi Riau disumbangkan 30 persen di antaranya atau sekitar 222.330 barel per hari. Kontribusi lifting minyak dan kondensat minyak dari wilayah kerja Satuan Kerja Khusus Pelaksana Kegiatan Usaha Hulu Minyak dan Gas Bumi (SKK Migas) Sumatera Bagian Utara (Sumbagut), berasal dari sumber produksi utama dari Blok Rokan yang dikelola PT Chevron Pacific Indonesia.. Target APBN 2019 untuk 9 perusahaan Kontraktor Kontrak Kerja Sama (KKKS) produksi berkontribusi di wilayah operasi Sumbagut sekitar 211.939 barel per hari atau 4,9 persen lebih tinggi dari target APBN, selain Chevron, terdapat KKKS Produksi minyak lainnya, di antaranya Pertamina EP, BOB BSP-PH, EMP Malacca Straits, EMP Tonga, PHE Siak, PHE Kampar dan PHE NSO-NSB dan SPR Langgak. (riau, 2019)

Berikutnya adalah penyumbang kedua terbesar adalah Mobil Cepu Ltd. memberikan kontribusi perolehan lifting minyak bumi Indonesia sebesar $26.90 \%$ dari total lifting minyak bumi Indonesia.

SKK Migas adalah lembaga negara yang diberi tanggung jawab untuk mengawasi dan mengendalikan seluruh kegiatan para Kontraktor Kontrak Kerja Sama (KKKS), termasuk proses lifting migas. Saat ini, SKK Migas mengawasi lifting pada 237 titik yang tersebar di seluruh Indonesia.

Pengawasan lifting, dilakukan bersama Pengawas lifting SKK Migas, KKKS, dan pembeli yang biasanya diwakilkan oleh surveyor. Alat ukur yang digunakan juga secara berkala dikalibrasi dan disertifikasi oleh Direktorat Metrologi. Khusus untuk ekspor, petugas bea dan cukai juga ikut melakukan pengawasan. Untuk lifting minyak dan kondensat dengan kapal, pengawasan dilakukan di setiap pengapalan di terminal. Sedangkan pengawasan lifting gas melalui pipa dilakukan pada setiap akhir bulan pukul 24.00 di titik penyerahan.

Pengawasan yang dilakukan selama proses lifting, antara lain adalah memastikan bahwa alat ukur yang digunakan masih berlaku sah sebagai alat ukur untuk jual-beli migas. Selanjutnya Pengawas lifting menyaksikan pengukuran tinggi cairan minyak/kondensat dan juga air bebas di tangki timbun, suhu minyak, dan pengambilan contoh untuk dilakukan analisis laboratorium. Selanjutnya Pengawas lifting dan surveyor akan mengawasi KKKS dalam melakukan analisis laboratorium, untuk menentukan densitas atau berat jenis dari minyak/kondensat dan impurities yang terkandung di dalamnya yang biasanya dikenal dengan basic sediment and water (BS\&W). Pengawas lifting selanjutnya melakukan pengawasan terhadap transfer minyak dan kondensat ke kapal, setelah mencapai batas sesuai dengan dokumen instruksi pengapalan. Proses transfer minyak dan kondensat ke kapal tergantung pada jumlah volume yang ditransfer dan kapasitas pompa.

Untuk terminal yang menggunakan sistem meter dalam serah terima minyak/kondensat, setelah pengambilan tinggi cairan minyak/kondensat, suhu, dan sampel. Kemudian minyak mulai dipompakan ke kapal, setelah aliran stabil dilakukan proving meter, yang bertujuan menentukan faktor meter dalam perhitungan akhir meter. Untuk terminal yang menggunakan sistem meter, biasanya terdapat automatic sample yang diambil dari lajur aliran minyak/kondensat ke dalam tabung sampel. Kira-kira dua jam sebelum pemompaan berakhir, tabung sampel ini diambil untuk dilakukan analisis di laboratorium dan sampel yang diambil disegel oleh surveyor untuk 
dibawa ke kapal sebagai master sampel, pelabuhan tujuan, dan pertinggal di laboratorium.

Setelah pemompaan minyak/kondensat ke kapal selesai, kembali lagi Pengawas lifting SKK Migas dan surveyor melakukan pengukuran akhir tangki timbun dan pengukuran suhu. Untuk menentukan seberapa banyak minyak/kondensat yang telah dipompakan ke kapal berdasarkan pengukuran tangki timbun. Atas minyak/kondensat yang telah dipompakan di kapal, petugas kapal dan KKKS melakukan pengukuran angka kapal. Pengukuran angka kapal lebih rumit, karena posisi kapal tidak tetap sebagaimana tangki tim timbun. Pengukuran di kapal harus memperhatikan draft kapal, posisi di depan dan belakang kapal dihitung berapa centimeter kemiringannya. Ini yang dikenal dengan istilah koreksi trim. Kemudian dikoreksi juga dengan kemiringan kapal, apakah menjauh dari dermaga/sebelah kanan (by starboard) atau mendekat ke dermaga/kiri (by port), yang disebut juga koreksi list.

Tahap selanjutnya angka perhitungan kapal dibandingkan dengan angka meter (bila ada meter) dan angka tangki. Perbedaan perhitungan angka kapal dengan angka meter atau angka tangki tidak boleh lebih dari $0,5 \%$. Apabila terjadi perbedaan harus dicari penyebabnya dan dibuatkan berita acara serta surat protes akibat perbedaan tersebut.

Selesai melakukan perhitungan angka meter, angka tangki, dan angka kapal. Pengawas lifting, Surveyor dan pihak terminal menandatangani tiga dokumen yaitu surat keterangan asal (certificate of origin), sertifikat jumlah muatan (certificate of quantity), dan sertifikat mutu (certificate of quality), sebagai dasar bagi kapten/nakhoda kapal untuk membuat Bill of Lading (B/L) yang merupakan dasar penagihan dari Negara atau KKKS kepada pembeli minyak dan kondensat.

Sedemikian banyaknya proses pengawasan lifting, terkadang membuat Pengawas lifting kurang istirahat di waktu malamnya. Selain naik dan turun tangki, Pengawas lifting juga harus teliti dalam melakukan perhitungan-perhitungan serta pengamatan pada waktu pengujian laboratorium. Tentu saja memerlukan fisik yang prima. Oleh karena itu, setiap Pengawas lifting harus memiliki berkas MCU yang fit for work, minimal Fit with note yang tidak membahayakan dirinya apabila melakukan pekerjaan pengawasan lifting. Demi untuk menjaga pendapatan negara, Pengawas lifting rela untuk kerja keras dan kurang istirahat. Dapat dibayangkan apabila dalam sewaktu harus naik tangga 4 tangki timbun.

Khusus untuk lifting minyak, SKK Migas tidak hanya mengatur minyak bagian negara, tetapi juga mengatur minyak yang menjadi bagian kontraktor KKS. Guna mempermudah pengelolaan, SKK Migas membentuk Forum Shipcoord (Shipping Coordination Meeting) yang rutin diselenggarakan setiap minggu. Forum ini berfungsi mengatur jadwal lifting seluruh minyak yang diproduksi di Indonesia, baik yang menjadi bagian negara maupun kontraktor KKS. Melalui pengaturan yang terkoordinasi, lifting diharapkan bisa berjalan lancar dan tidak mengganggu produksi serta menghindari melimpahnya stok minyak di tempat penampungan (high inventory).(MIGAS A. S., 2019)

Pedoman untuk melaksanakan pekerjaan yang dilakukan oleh pengawas lifting ada pada Pedoman Tata Kerja Nomor: PTK-062/SKKO0000/2016/S0 Tentang Manajemen Operasi Produksi Minyak Dan Gas Bumi.

Dari 237 titik serah seluruh Indonesia, SKK MIGAS sudah melakukan sertifikasi Kompetensi Loading Master di LSP PPT MIGAS sejumlah 131 orang pada tahun 2018 -2019, sementara 
data dari LSP PPT MIGAS ada 156 orang yang sudah mengambil Sertifikasi kompetensi Loading Master ini, ada 25 orang di luar SKK MIGAS yaitu dari Pertamina Asset 4, asset 5, Energy Equity EPIC Sengkang, BPMA dan lainnya. Dari data ini masih di bawah 20\% pengawas lifting yang tersertifikasi Loading Master. Asumsi setiap titik ada 5 orang petugas pengawas lifting.

Uji sertifikasi ini meliputi ujian teori, praktik / simulasi pengukuran dan perhitungan minyak bumi/ BBM/ Produk turunannya, kemudian verifikasi peralatan serta pengisian dan verifikasi dokumen serah terima minyak.

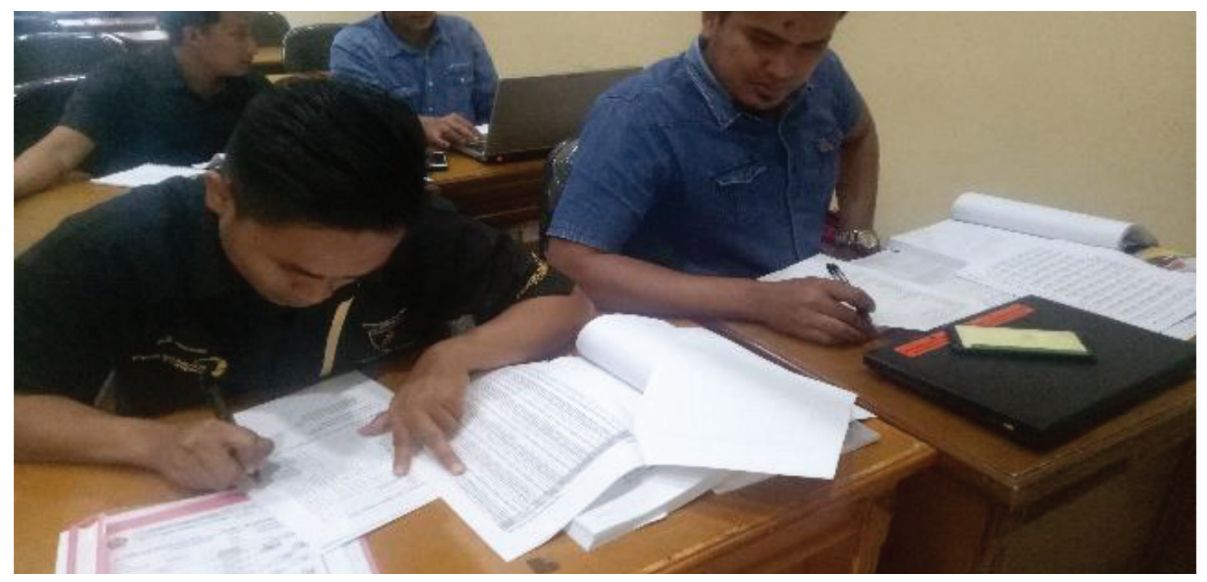

Gambar 7 verifikasi hasil pengukuran dan perhitungan volume standar

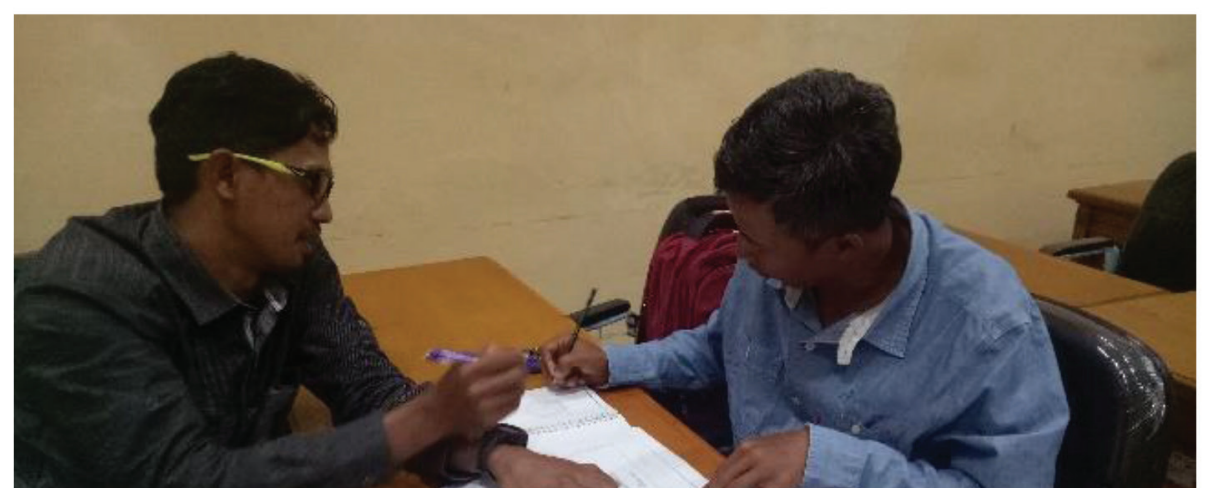

Gambar 8 Diskusi hasil perhitungan standar

\section{KESIMPULAN}

1. Loading Master adalah petugas lapangan yang bertanggung jawab terhadap kelancaran kegiatan serah terima minyak bumi dan produk turunannya.

2. Loading Master juga bertugas dan menandatangani dokumen serah terima seperti Loading Agreement, Tanker Time Sheet, Surat Perbedaan Angka Muat (Letter of Discrepancy), Berita acara Serah Terima, Berita Acara Pemeriksaan Fisik, Notice of Readiness, Dry Certificate, Certificate of Quantity, Compartement Logsheet sehingga butuh kompetensi yang handal agar tidak terjadi kekeliruan dalam perhitungan sesuai standar yang berlaku baik dari ASTM atau IP. 
3. Dari 237 titik serah masih banyak yang belum tersertifikasi, yang sudah tersertifikasi masih di bawah $20 \%$.

4. LSP PPT MIGAS sebagai Lembaga Sertifikasi Profesi yang sudah terakreditasi siap melaksanakan sertifikasi Loading Master.

\section{DAFTAR PUSTAKA}

MIGAS, A. S. (2019, Juli 24). memahami-lifting-migas. Retrieved from https://balikpapan.prokal.co: https://balikpapan.prokal.co/read/news/245921-memahami-lifting-migas

MIGAS, D. J. (2019). LAPORAN KINERJA DIREKTORAT JENDERAL MIGAS. Jakarta: Direktorat Jenderal Migas.

MIGAS,S. (2016,December 13). Nomor: PTK-062/SKKO0000/2016/S0 MANAJEMEN OPERASI PRODUKSI MIGAS. PEDOMAN TATA KERJA. Jakarta, Jakarta, Indonesia: SKK MIGAS.

MIGAS, T.B.(2019,February. TINGKATKAN PRODUKSI DAN lifting MIGAS. 70, p. 6.

Riau, S. (2019, Februari 25). https://kumparan.com/. Retrieved from kumparan: https://kumparan.com/selasar-riau/30-persen-produksi-minyak-nasional-disumbangkan-dari-perut-bumi-riau-1551102030270025339 